\title{
The Effectiveness of Interactive Learning in Manufacturing Engineering
}

\author{
Nadia Abdul Rani ${ }^{1,2}$, Faieza Abdul Aziz ${ }^{1 *}$ and Rohidatun $M, W .^{3}$ \\ ${ }^{1}$ Department of Mechanical and Manufacturing Engineering, Faculty of Engineering \\ Universiti Putra Malaysia, 43400 UPM Serdang, Selangor,Malaysia \\ ${ }^{2}$ Kolej Komuniti Kepala Batas,No.87, Lorong Bertam Indah, Taman Bertam Indah, \\ 13200 Kepala Batas Pulau Pinang,Malaysia \\ ${ }^{3}$ Faculty of Mechanical Engineering,Universiti Teknologi MARA, Cawangan Pulau Pinang, \\ Kampus Permatang Pauh, Pulau Pinang, Malaysia
}

\begin{abstract}
Interactive learning is a pedagogical model that encourages students to be part of the lesson instead of passive observers, quietly sitting at a desk taking notes or memorizing information. Students interact with the material, each other and the teacher in an active way. The new emerging technologies that can overcome some of the potential difficulties in this area includes computer graphics, augmented reality, computational dynamics, and virtual worlds. Therefore, the manufacturing industry relies on new design concepts and methods undertake the challenges in integrating technologies to expedite the march towards industrial revolution 4.0.This paper reviews and investigates the current context of the use of interactive learning such as Virtual Reality(VR),Augmented Reality(AR),Computer aided design and manufacturing(CADCAM), computer graphics, computational dynamics and new emerging technologies that effect on students and lectures in learning and teaching environments for Manufacturing Engineering. Interactive learning is part of the factors that could influence the self-learning and regulations environments.
\end{abstract}

Key words: Interactive Learning, Manufacturing, Technology

\section{INTRODUCTION}

The $4^{\text {th }}$ industrial revolution and the digital transformation are prevailing factors in the manufacturing industry. Therefore, digital design and manufacturing technologies provide a great support for product realization from design conception and engineering to manufacturing, sales and services of a product. Looking from the past, their developments and evolutions are driven greatly by other technological advances, such as those in materials, electronics, software and ICT. The real time aspect distinguishes the fields of human-machine system and human-computer interaction are strongly related [1]. Human-computer interaction (HCI) is a multidisciplinary field focused on the interfaces between people (users) and computers in which psychology and other social sciences unite with computer science and related technical fields with the goal of making computing systems are both useful and usable. Human-Machine Interaction (HMI) is describe as the interaction and communication between human users and a machine, a dynamic technical system. Emotional behaviour has been analysed base on nonpropositional movement qualities, example: amplitude, speed and fluidity of movement,[2]. Nowadays the education driven by global competition and the need for fast adaptation of students to the ever-changing market requests. The fourth industrial revolution (Industry 4.0) and its embedded technology diffusion progress is expected to grow exponentially in terms of technical change and socioeconomic impact. Coping with such transformation require a holistic approach that encompasses innovative and sustainable system solutions and not just technological ones. Interaction is part of nature that cannot be separated with human. Human interaction is an interaction between learners

Corresponding Author: Faieza Abdul Aziz, Department of Mechanical and Manufacturing Engineering, Faculty of Engineering, Universiti Putra Malaysia, 43400 UPM Serdang, Selangor, Malaysia, +60389466346 
and teacher and among learners during the learning process, and which may include synchronous and asynchronous modes and face to face and electronic mode. The concept of interactivity touches upon interplay, cooperation, or some kind of exchange between two or more actors, which allows for at least two possible interpretations: 1) either as interaction between a human and a machine (from a technological point of view); or 2) as a communication and exchange between people (from a pedagogical point of view) [3]. As stated by Bucy and Toa [4], interactivity can be understood as a technological feature of mediated surroundings where people communicate and exchange information and interact with technology or with other people through technology. Within the German Industries 4.0 initiative learning factories with focus on Industry 4.0 are emerging, the core subjects of Industry 4.0 as digitalization and networked production gained importance in the latest learning factories. The classification is based on the 'Fraunhofer Layer Model of Industry 4.0 Value Creation, [5]. Merkel et al., [6] include interactive assistance systems for workers, real-time business intelligence and simulation tools for single processes and for the overall material flow within the concept of the learning factory for cyberphysical production systems (LVP)

\section{INTERACTIVE LEARNING}

The interactive technology has been developed as a supportive tool to enhance teaching and learning process especially in Manufacturing Engineering Course such as machining technology, product design, automotive and aerospace where learning experience is needed as a competency skill. Numbers of interactive technology tools and mobile apps equipped with suitable software and application are advantages used in various branches of practices at present time. Examples of application of virtual manufacturing in area of production systems design is on Fig. 1 [7].

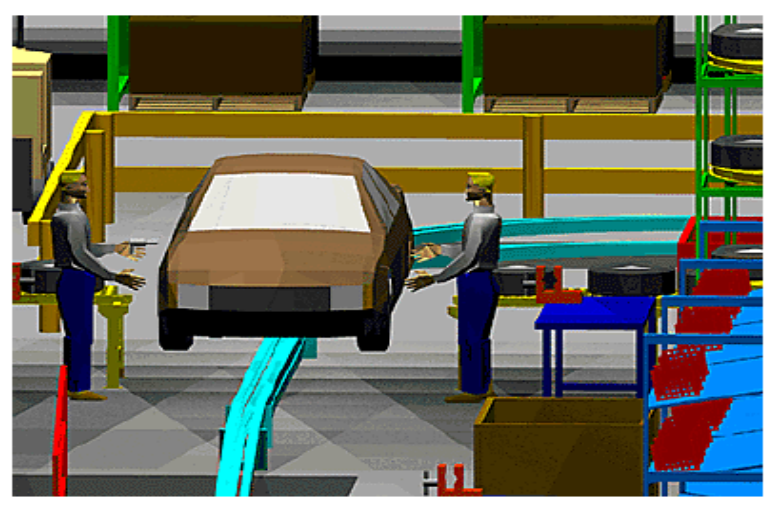

Fig.1. Virtual manufacturing in practice

\section{VIRTUAL REALITY (VR)}

Virtual Reality (VR) is scientifically defined as an application of the computer technology to create an effect of interactive, three-dimensional world, in which objects have spatial form. Main criterion of division of VR system is a level of immersion of user into virtual environment. VR is scientifically defined as an application of the computer technology to create an effect of interactive, three-dimensional world, in which objects have spatial form. Main criterion of division of VR system is a level of immersion of user into virtual environment. Valvo, Licari, and Adornetto [8] used Virtual Reality to verify the toolpath and detect any collision occurred in CNC Machining. The immersion is achieved mostly by stereoscopic projection, giving the user an illusion of spatial depth. Grajewski [9] applied the immerse VR and the haptic technologies during the complex process of design and virtual prototyping of the manufacturing workplaces characterized with a high level of ergonomic quality as Figure 2. VR is widely used in the industry and becoming more affordable for end users 


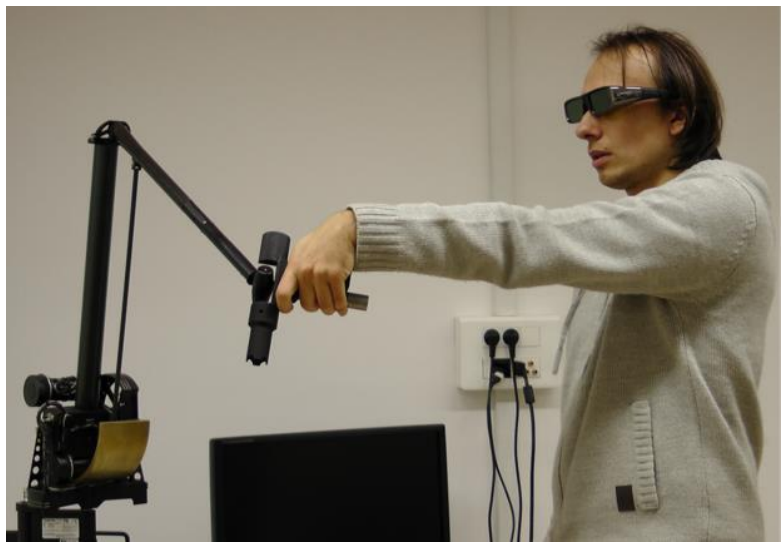

Fig. 2. Manipulation using prototype of the weld gun on a haptic device

VR also has been used as a teaching methodology for practical design course focusing on learning about VR by stimulating interdisciplinary industrial projects. Nishizawa et al., [10] has developed a virtual game with interactively changeable $3 \mathrm{D}$ graphics to improve the situation of learning vector equations in $3 \mathrm{D}$ space in linear algebra as Figure 3



Fig. 3. Designing an avatar for the game

\section{AUGMENTED REALITY (AR)}

During last few decades, many professionals and researchers have been developing pragmatic theories and application for the adoption of Augmented Reality into both academic and corporate settings. AR is more powerful due to the applications are through personal computers and mobile devices and several educational approaches with AR technology are more feasible. It is a new metaphor in computer interaction technology by forming changes in the field of interaction and improve the user experience when operating the application, [11]. Kose, Koc, and Yucesoy, [12] used a mobile AR tool to provide a supportive, e-learning material for students by viewing 3D animations and special-made videos to have more idea about a course subject. AR as a key technology of concept Industry 4.0 to support learning activities and becomes a trend in education and AR based methods are proven to be affective teaching aids for engineering course. Devedzic et al., [13] implemented AR learning tool to helps students to develop a holistic understanding of geometric shapes manufacturing features, part models, spaces and design process as Figure 4. AR is one technology that dramatically shifts the location and timing of teaching and learning process in education. Two stages of process were used by Ma et al., [14] in implementing AR-Based for CNC simulation by transferring the construction of correspondent point pairs between model and real scenes to the calculation of the affine matrix between a pair of 2D images. Novak-Marcincin et al., [15] as Figure 4 introduced the possibilities of using special virtual tools named augmented reality(AR) for manufacturing process in product manufacturing area. In teaching CAD Courses, [16] indicate AR capability as an effective tool to be used in maintenance process and inspection for automotive industry by providing user an information needed about process and procedure directly on the working environment.

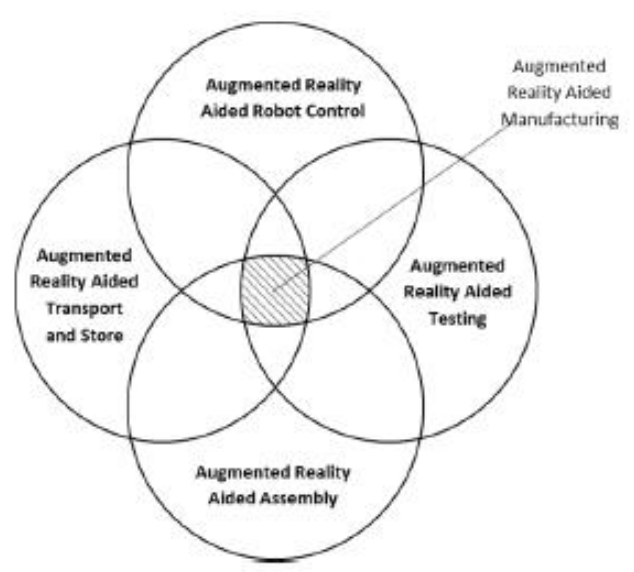

Fig. 4. Main idea of augmented reality aided manufacturing (ARAM) 


\section{COMPUTER AIDED DESIGN AND COMPUTER AIDED MANUFACTURING (CADCAM)}

The ability to design good products has always been an important factor for the success of a manufacturer in the market. In CNC machines, it is possible to produce very complex shape, but really needed a sophisticated CAM system such as MASTERCAM, FUSION and others, skilled users and number of time-consuming test and in order to obtained the best work and results. Different teaching methodologies and implementation of program in Mechanical and Manufacturing course has being introduced to improvise the teaching and learning process in CNC machining. Iqbal, Sheikh, and Abdul Samad [17] used CADCAM software as a feature based methodology in a manufacturing lab course and implement separated levels of learning in CAD and CAM, refer to Figure 5. This is to inculcate the knowledge in the area of CAM software for metrological study and data generation for statistical analysis. For development of product and production, CADCAM maintain a significant role in interaction activities between human and computers by

simplifying an engineer's work in collecting using and sharing information so that human can maximize the usage of their unique abilities, [18]. A CAD model of new solution innovative tool using CAD model was elaborated in CAM system program for machining this tool using 5-axis DMG MORI DMU 50 milling machine, [19]. A standard has been established entitled ISO14649 standard focusing in manufacturing and highlights the various issues for $\mathrm{CAD} / \mathrm{CAM}$ vendors; machine control vendors and manufacturing users based on the ability in generating an NC tool path is now commonplace from CAD/CAM systems, [20].

\section{WEB TECHNOLOGIES}

Recent studies have shown the urgency for future engineers and knowledge workers to adopt new teaching curricula in order to cope with the increasing industrial requirements. Smaill [21] used a web-based tool used for skills practice and summative assessment in electrical engineering that delivered individualized tasks, marks student responses, supplies prompt feedback, and logs student activity. Tan et al., [22] defined that students were very positive towards the incorporation of interactive authentic activities and found the authentic learning environment to be very relevant to their learning and became more engaged and actively involved in their learning process. These results show strong and encouraging support for the development of multimedia web-based modules that are grounded in authentic learning and sound design principles, and an innovative teaching and learning strategy in a technology-backed class, refer as Figure 5 and Figure 6. A web-based application was proposed by Mavrikios et al., [23] for classifying Teaching and Learning Factories with special installations infrastructures that offer industrial-grade equipment and a modern ICT installation for the operation of both paradigms, either in a local or distributed mode. The web-based application offers a way of storing the knowledge, related to such installations and creates relations that can be easily classified.



Figure 5: Lessons

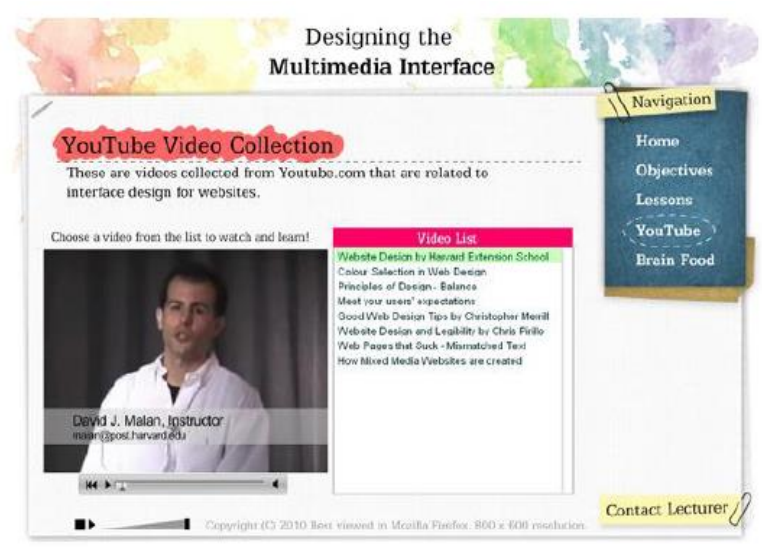

Figure 6: The YouTube Videos page 


\section{EFFECTS OF INTERACTIVE LEARNING}

Similar to the evolution and progress of technology over the past 100 years, change has been synonymous with the field of technology and engineering education [24, 25]. Nowadays, the needs of young people who are skillful in and enthusiastic about science and who view science as their future career field. Ensuring that we will have such young people requires initiatives that engage students in interesting and motivating science experiences. Van Dijk, Van Der Berg, and Van Keulen, [26] indicated that interactive teaching will not automatically result in students who are more activated, and provided additional insight into conditions for successful interactive teaching but interactive teaching was shown to influence positively student motivation. Froyd et al., [27] identified five major shifts in engineering education and the $5^{\text {th }}$ shift indicates the technologies (e.g., the Internet, intelligent tutors, personal computers, and simulations) have been predicted to transform education for over 50 years. A review by Fong, Kwan, and Wang [28] on a selection of the literature to contrast the value of physical and virtual investigations and to offer recommendations for combining the two to strengthen science learning. Students can investigate scientific phenomena using the tools, data collection techniques, models, and theories of science in physical laboratories that support interactions with the material world or in virtual laboratories that take advantage of simulations. Murat [29] investigated (AR) interactive technology significantly enhanced the development of the university students' laboratory skills. AR technology both improved the students' laboratory skills and helped them to build positive attitudes towards physics laboratories. Contemporary manufacturing is called to encounter the increasing industrial requirements of production related technologies, tools and techniques [30]. In order to cope with the advances in technology, constitutes a promising factor considering an improving and innovative performance of European manufacturing [31]. However, as industrial education requires the direct evolvement of engineers in the manufacturing field, a theoretical approach inside a classroom would not be sufficient to meet the existing training criteria. Hence, the innovation of new teaching approaches is required, that are able to combine the manufacturing education and the industrial practice, import advanced knowledge into production, balance the resource-based manufacturing (labor and capital) and knowledge-based manufacturing (information and knowledge) and confirm a steady industrial growth [32]. Study conducted by $[33,34]$ suggested that a combination of interactive learning using AR system and training in VR platform was the best method in learning new assembly tasks.

\section{CONCLUSION}

Interactive Technology enhanced interactive learning aims to design, develop and describe the application of Information and Communication Technology in different educational process. Contemporary and rapidly changing society needs people with high digital and technological competences and skills. Due to this changes especially in the modern society when intelligent mobile devices become popular, the Internet breaks through the restrictions on time and space and becomes a ubiquitous learning tool. Designing teaching activity for digital learning and flexibly applying technology tools are the key issues for current information technology integrated education. In other words, the promotion of digital learning could provide alternative innovation of class teaching. With the advance of information technology and the relevant technologies, digital learning would be accepted by students and teachers. It is the goal and task of teachers to have students receive systematic knowledge through network and possess. It is to be realised that world is witnessing radical changes as information technology alters how we communicate with each other and the machines that serve us. The arrival of the Internet and mobile phones has spearheaded these changes making possible the vision for "anyone, anytime, anyplace" communication, accelerating the pace of globalisation, as services become affordable international commodities.

\section{ACKNOWLEDGEMENT}

The authors would like to acknowledge IPN Education Group and financial support from GIPP UPM, Vot Number: 9323709

\section{REFERENCES}

[1] Johannsen, G., (2009) Human-Machine Interaction, Control System, Robotics and Automations -Vol XXI 
[2] Castellano,G., Kessous, L., Caridakis, G. (2008), Emotion Recognition through Multiple Modalities : Face, Body, Gesture, Speech

[3] Severin \&amp; Tankard, Communication Theories: Origins, Methods and Uses in the Mass Media, 5th Edition | Pearson. (n.d.). https://www.pearson.com/us/highereducation/program/Severin-CommunicationTheories-Origins-Methods-and-Uses-in-the-MassMedia-5th-Edition/PGM83105.html

[4] Bucy, E. P., \& Tao, C.-C. (2007). The Mediated Moderation Model of Interactivity. Media Psychology, 9(3), 647-672. https://doi.org/10.1080/15213260701283269

[5] Neugebauer, R., Hippmann, S., Leis, M., \& Landherr, M. (2016). Industrie 4.0 - From the Perspective of Applied Research. https://doi.org/10.1016/j.procir.2016.11.002

[6] Merkel, L., Atug, J., Merhar, L., Schultz, C., Braunreuther, S., \& Reinhart, G. (2017). Teaching Smart Production: An Insight into the Learning Factory for Cyber-Physical Production Systems (LVP). Procedia Manufacturing, 9, 269-274. https://doi.org/10.1016/j.promfg.2017.04.034

[7] Ing. Jozef Barna, Ing. Veronika Fecova, prof. Ing. Jozef Novak-Marcincin, PhD., Ing. Jozef Torok, Utilization of Open Source Application in Area of Augmented Reality Assembling Processes, MANUFACTURING TECHNOLOGY June 2012, Vol. 12, No. 12

[8] Valvo, E. Lo, Licari, R., \& Adornetto, A. (2006). International journal of internet science. International Journal of Online Engineering (iJOE) (Vol. 8). [publisher not identified]. Retrieved from http://online-journals.org/index.php/ijoe/article/view/2047/2213

[9] Grajewski, D., Górski, F., Zawadzki, P., \& Hamrol, A. (2013). Application of virtual reality techniques in design of ergonomic manufacturing workplaces. In Procedia Computer Science. https://doi.org/10.1016/j.procs.2013.11.035

[10] Nishizawa, H., Shimada, K., Ohno, W., \& Yoshioka, T. (2013). Increasing reality and educational merits of a virtual game. In Procedia Computer Science. https://doi.org/10.1016/j.procs.2013.11.005

[11] Martono, K. T. (2011). Augmented Reality Sebagai Metafora Baru dalam Teknologi Interaksi Manusia dan Komputer, 1(2), 60-64.

[12] Kose, U., Koc, D., \& Yucesoy, S. A. (2013). An augmented reality based mobile software to support learning experiences in computer science courses. Procedia Computer Science, 25, 370-374. https://doi.org/10.1016/j.procs.2013.11.045

[13] Devedzic, G., Ghionea, I. G., Fiorentino, M., Di Bari, P., Cukovic, S., Ghionea, I., \& Subburaj, K. (2016). Engineering Design Education for Industry
4.0: Implementation of Augmented Reality Concept in Teaching CAD Courses. Retrieved from

https://www.researchgate.net/publication/301222 242

[14] Ma, Z. Y., Chen, Y. P., Yuan, C. M., \& Zhou, Z. D. (2006). An Efficient 3D Registration Method Using Markerless Image in AR-Based CNC Machining Simulation (pp. 175-184). Springer, Berlin, Heidelberg. https://doi.org/10.1007/11941354_19

[15] Novak-Marcincin, J., Barna, J., Janak, M., \& Novakova-Marcincinova, L. (2013). Augmented Reality Aided Manufacturing,International Conference on Virtual and Augmented Reality in Education. Procedia Computer Science, 25, 23-31. https://doi.org/10.1016/j.procs.2013.11.004

[16]E. Alostad , F. Abdul Aziz. (n.d.). Journal of fundamental and applied sciences. Journal of Fundamental and Applied Sciences (Vol. 10). University of $\mathrm{El}$ Oued. Retrieved from https://www.ajol.info/index.php/jfas/article/view/ 171911/161311

[17]Iqbal, H., Sheikh, A. K., \& Abdul Samad, M. (2014). Introducing CAD/CAM and CNC machining by using a feature based methodology in a manufacturing lab course, a conceptual frame work. IEEE Global Engineering Education Conference, EDUCON, (April), 811-818. https://doi.org/10.1109/EDUCON.2014.6826189

[18] Li, Y., Hedlind, M., \& Kjellberg, T. (2015). Usability evaluation of CADCAM: State of the art. In Procedia CIRP. https://doi.org/10.1016/j.procir.2015.01.053

[19] Mikolajczyk, T., Latos, H., Paczkowski, T., Pimenov, D. Y., \& Szynka, T. (2018). Using CAD CAM system for manufacturing of innovative cutting tool. In Procedia Manufacturing. https://doi.org/10.1016/j.promfg.2018.03.025

[20] Rosso Jr, R. S. U., Allen, R. D., \& Newman, S. T. (2002). Future issues for CAD/CAM and intelligent $\mathrm{CNC}$ manufacture. In International Manufacturing Conference (p. 10). https://doi.org/10.1017/CBO9781107415324.004

[21] Smaill, C. (2006). The implementation and evaluation of OASIS, a web-based learning and assessment tool in electrical engineering. Proceedings - Frontiers in Education Conference, FIE, (December 2006). https://doi.org/10.1109/FIE.2006.322482

[22] Tan, H. Y., Kwok, J. W., Neo, M., \& Neo, T. (2010). Enhancing student learning using multimedia and web technologies: Students' perceptions of an authentic learning experience in a Malaysian classroom. Curriculum, Technology \& Transformation for an Unknown Future. Proceedings Ascilite Sydney 2010, (April), 951- 
Nadia, Faieza \& Rahidatun/ Journal of Engineering and Science Research, 2(6) 2018, Pages: 10-16

962. $\quad$ Retrieved from http://www.ascilite.org/conferences/sydney10/pro cs/Tan-full.pdf

[23] Mavrikios, D., Sipsas, K., Smparounis, K., Rentzos, L., \& Chryssolouris, G. (2017). A Webbased Application for Classifying Teaching and Learning Factories. Procedia Manufacturing, 9, 222-228.

https://doi.org/10.1016/j.promfg.2017.04.002

[24] Hill, R. B. (2006). New perspectives: Technology teacher education and engineering design.Journal of Industrial Teacher Education , 43 (3), 45-63. Retrieved fromhttp://scholar.lib.vt.edu/ejournals/JITE/v43n 3/pdf/hill.pdf

[25]Lewis, T. (2004). A turn to engineering: The continuing struggle of technology education for legitimization as a school subject. Journal of Technology Education, 16 (1), 21-39. Retrieved from

http://scholar.lib.vt.edu/ejournals/JTE/v16n1/pdf/l ewis.pdf

[26] Van Dijk, L. A., Van Der Berg, G. C., \& Van Keulen, H. (2001). Interactive lectures in engineering education. European Journal of Engineering Education, 26(1), 15-28. https://doi.org/10.1080/03043790123124

[27] Froyd, J. E., Wankat, P. C., \& Smith, K. A. (2012). Five Major Shifts in 100 Years of Engineering Education. Proceedings of the IEEE, 100(Special Centennial Issue), 1344-1360. https://doi.org/10.1109/JPROC.2012.2190167

[28] Fong, J., Kwan, R., \& Wang, F. L. (2008). A Mixed Reality Teaching and Learning Environment. LNCS (Vol. 5169).

[29] Murat Akçayır,Gökçe Akçayır,Hüseyin Miraç
Pektaş,Mehmet Akif Ocak (2016), Augmented reality in science laboratories: The effects of augmented reality on university students' laboratory skills and attitudes toward science laboratories.

https://doi.org/10.1016/j.chb.2015.12.054

[30] IMF (International Monetary Fund). World Economic Outlook - Hopes, Realities, Risks, World Economic and Financial Survey. International Monetary Fund (2013)

[31] Chryssolouris, G., Mavrikios, D., Mourtzis, D., Manufacturing Systems: Skills \& Competencies for the Future. Procedia CIRP Keynote paper of the 46th CIRP Conference on Manufacturing Systems, 7 (2013) 17-24.

[32] Chryssolouris, G., Mavrikios, D., Rentzos L., The Teaching Factory: A Manufacturing Education Paradigm. Procedia CIRP Keynote paper of the 49th CIRP Conference on Manufacturing Systems, (2016) 44-48.

[33] Rohidatun, M. W., Faieza, A. A., Rosnah, M. Y., Saad, N. H., \& Rahinah, I. (2006). International journal of applied engineering research. International Journal of Applied Engineering Research (Vol. 11). Research India Publications. Retrieved from https://uitm.pure.elsevier.com/en/publications/dev elopment-of-virtual-reality-vrsystem-with-hapticcontroller-an

[34] Rohidatun, M. W., Faieza, A. A., Rosnah, M. Y., \& Hayati, S. N. (2017). Develop a Virtual and Augmented Reality System to Enhance Learning and Training Assembly. Journal of Computational and Theoretical Nanoscience, 14(11),5617-5620. https://doi.org/10.1166/jctn.2017.6992 